\title{
The Politics of Regulatory Redistribution Revisited
}

\author{
Kim, Junseok \\ (Gyeonggi Research Institute)
}

$\langle$ CONTENTS〉

I. Introduction

II. Caveats of Regulatory Redistribution Theories

1. Distributive Approach to Economic Regulation

2. Majoritarian Approach to Economic Regulation

3. Overlooked: The Role of Regulatory
Bureaucracy on Regulatory

Redistribution

III. Constructing an Empirical Model of Regulatory Redistribution

1. Dependent Variable

2. Independent Variables

IV. Results

V. Concluding Remarks

- Keyword: Regulation, Redistribution, Telecommunication

\section{【ABSTRACT】}

Redistribution- whether in the classical sense of who gets what at whose expenses, or in the contemporary sense of how interest group gains capture from trade- undeniably forms part of economic regulation. But how does economic regulation redistribute wealth in one form or the other from one group to others? Does economic regulation usually favor a group of superior ability to manipulate the political process? If does, under which conditions? This article investigates the nature of regulatory redistribution by assessing the conditional impact of economic, political, and institutional factors in American states regulatory policymaking. We find there is the likely behavioral difference between regimes of direct election and political appointment regarding regulatory bureaucracypopular election of regulators is more likely to lead more consumer-oriented regulatory policies because elected regulators are relatively more responsible for 
their core constituents, voters. This implicitly suggests our argument that how regulatory bureaucracy behaves over redistribution matter is conditional upon the way regulatory bureaucracy is positioned in the structure of bureaucratic politics.

\section{I . Introduction}

Current debate on economic regulation focuses on regulatory redistribution. Redistribution- whether in the classical sense of who gets what at whose expenses, or in the contemporary sense of how interest group gains capture from trade- forms part of economic regulation. But how does economic regulation redistribute wealth in one form or the other from one group to others? Does economic regulation usually favor a group of superior ability to manipulate the political process? If does, under which conditions? Is the nature of economic regulation exclusively distributive toward special interest groups or is it foremost majoritarian?

The past thirty years have witnessed an explosion of research to discover the nature of economic regulation (Baron 1995). The findings are large and diverse, the theoretical implications are inconclusive and often in disagreement with the quality of the evidence supporting them. Variants of the distributive approaches, which have long dominated thinking about the nature of economic regulation, have not properly addressed the role of politics. Others have sought the evidence to counter the dominance of the distributive perspective ${ }^{1)}$. However, their implications have yet to be further developed. The lack of easily accessible quantitative data is the main reasons for the dearth of empirical evidence of the political aspects of regulation.

This paper aims to overcome these problems by collecting more sophisticated data about economic/political institutions and their changes over time and constructing an empirical model that captures the dynamic structure of regulatory redistribution across both time and space. Drawing on arguments implicit in previous regulation studies, this article attempt to specify the theoretical underpinnings of state telecom deregulation and take into account the politics of regulatory structure as a whole. This leads us first to assess the conditional impact of economic, political, and institutional actors on American state regulatory policymaking.

1) See Berry 1979, 1983; Berry and Berry 1990, 1994; Cohen 1992; Fuchs 1984; Teske 1989, 1991, 1995; Teske et al. 1993; Levy and Spiller 1996(but see Ka and Teske (2004)). 
This paper specifically focuses on state Public Utility Commissions(PUC) over the issue of cross-subsidy balance between residential users and large business corporations in local telephone industry during the 1990s. The AT\&T divestiture has led to a great diversity in overall regulatory landscape in the states and thus telecom regulation provides the ideal natural laboratory for empirical analysis, allowing us to test a wide range of economic, political and institutional factors suggested by the literature. Our primary econometric method is a pooled cross-sectional time series analysis with panel corrected standard errors(Beck and Katz 1995, 1996) that accounts for both random and fixed effects of the data over time and space.

The next section discusses the merits and faults of two major approaches on economic regulation: distributive and majoritarian. The scholarly literature in regulatory redistribution covers a wide range, but its theoretical underpinnings neatly fall into two classes: distributive and majoritarian approaches. Section III builds an empirical model. Section IV tests it and discusses the significance of this finding and some broader issues, while section $\mathrm{V}$ concludes.

\section{Caveats of Regulatory Redistribution Theories}

\section{Distributive Appreach to Econømic Regulation}

Beginning with Bernstein's(1955) seminal life cycle theory and progressing particularly to Stigler's(1971), the set of ideas known broadly as "capture theory" has influenced a variety of subsequent works in the field of regulation and has arguably emerged as the dominant approach to economic regulation. Economic regulation, as a rule, transfers a disproportionately large share of social wealth to organized interest groups at the expense of unorganized mass. It is thus inherently inefficient and undesirable in the context of social welfare(Stigler 1971; Peltzman 1976; Becker 1983). The argument is premised on the logic that regulated industries are better able to provide the financial resources and votes that politicians require to secure reelection and, in turn, politicians reward their patrons by crafting favorable regulation and exercising oversight of agencies in an amenable fashion ${ }^{2}$. Mass public has essentially little incentive to devote

2) The economic theory of regulation has been confronted with a variety of criticisms from institutional economics as well as other social sciences, especially political science. We discuss two main criticisms here: (1) Not enough attention has been given to the complex web of actors such as interest groups, legislatures, courts, executives, and bureaucrats; (2) The economic theory understates the importance of regulatory institutions and environments. 
effort or resources to become mobilized and even informed about comparative merits of regulatory policies. A single vote is both a weak indicator of preferences in multi-policy elections(and almost inconsequential for policy outcome) because benefits of such a policy change are widely spread among all participants in the population (Downs 1957; Olson 1965; Macey 1986). The results are a sort of regulatory capture that emerges endogenously through electoral process due to diffuse costs and concentrated benefits (Besley 2002, 2). Peltzman(1976, 1989) and Becker(1983) extend the distributive approach to take account of the deregulation of the airline, transportation, and public utility industries in the late 1970s and $1980 \mathrm{~s}^{3)}$.

Closely related to this academic trend are theories of congressional dominance (McCubbins and Schwartz 1985; Calvert et al. 1987; Banks and Weingast 1992). This version of distributive view considers Congress the dominant factor in regulatory decision-making. Bureaucrats hardly maintain their detached professionalism and often become merely passive agents of their principal, namely the legislature. This nevertheless corresponds to capture theory of Chicago school because close ties between legislators and interest groups ${ }^{4)}$.

\section{Majoritarian Approach to Econømic Regulation}

In early $20^{\text {th }}$ century, market failure perspectives have predominated in regulatory studies as the legacy of the common law doctrines of just prices and business affected with a public interest prevailed. Regulatory decisions should be made in an effort to balance the desire of various participants in order to nurture public interest. Scholars of economic regulation view traditional public utility regulation as a form or welfare state regulation. That is, the government has an obligation to protect the welfare of its citizens from potential economic harms and imperfect market and to provide essential services to every American family with reasonable prices(Cherry 2001). Regulation is a means of public authority for government to conduct its obligations. An industry may

3) Peltzman argues that no one can enjoy permanent dominance over policymaking; rather, each group is forced to share those regulatory benefits with other groups of competitors or even consumers that have sufficient stake and political resources to make effective demand. Becker(1983) asserts that technological change and economic growth facilitate the mobilization of opposition groups, thereby reducing the asymmetry of representation in the policy process.

4) Theorists of congressional dominance even admit that the legislature may not have complete control over the regulatory agency in question, perhaps due to the introduction of multiple principals competing for agency control (McCubbins et al. 1987; Moe 1992) or through the direct effect of one or another branch of government, such as the President through his appointment power(Wood 1991; Wood and Waterman 1993), or the courts(Spriggs 1996; Spence 1997). 
fail to operate with efficiency if one or more of three situations - negative externalities, inadequate information, and natural monopolies- cause market failures. Then, governments interfere with market in order to restore economic efficiency as well (Reagan 1987). Its applications, however, has been very limited due to its normative and philosophical characteristics.

A recent scholarship in New Institutional Economics(NIEs), political science, and public administration has refuted the distributive view of economic regulation over last two decades. Politics should be viewed different from economics, they argues, in that there is not always a monetary measures of outcomes, coalitions formed can be binding to all parties, and preferences are not necessarily immutable(Wilson 1980). Since, as Riker (1985) puts it, the outcome of the regulatory process should be understood mainly in terms of the utility of policymakers and not concentrated interests, the complexity and multidimensionality of their utility functions as suggested by Wilson points out to the infeasibility of previous distributive theory. If policymakers find changes to regulatory policy to be in their interests and/or they help to build or at lest not undermine their political careers, public opinion nevertheless matters. That is, elected policymakers care about how local constituents respond to their actions on policy reform and mostly do what their local public wants. Derthick and Quirk(1985) argue that during late 1970s, deregulations in airline, transportation, and telecommunication occurred since politics responded to the criticism of inefficient regulation, disperse interests, and a shift in mass attitude in favor of regulatory reforms. Regulatory outcomes can also be contingent on idiosyncratic changes in the attention of mass or elite public.

Considering this, Wilson(1980) presents a useful typology of four different regulatory regimes, depending on the distribution of costs and benefits. If costs and benefits are both widely distributed, then regulation takes place in a majoritarian regime and interest groups have little role. In the other three combinations, however, interest groups or concentrated economic actors play at least some role in actively seeking or opposing regulation. Of these, only the narrow costs and narrow benefits condition directly describes the regime in which the distributive view of economic regulation is presumed to be acting.

\section{Overleoked: The Role of Regulatory Bureaucracy on Regulatory Redistribution}

Historically, the distributive approach has become the mainstream view as the nature of economic regulation in the discipline while the majoritarian view has died away into the distance ${ }^{5}$. Of all, this is mainly due to a mass of fairly empirical evidence(Winston 
1993). Very few empirical works from majoritarian perspectives, by contrast, have been empirically tested. There are several reasons for that. First, with the exception of regulatory agencies and some interest groups, very few political actors get involved in the day-to-day business of regulation and intervene in agency decisions. Second, the impact of political institutions on regulatory outcomes is not always instantaneous or easy to detect. As Friedman(1993) notes, there are three types of "lag", in observation, decision and effect, which delay the effect of political changes on regulatory outcomes. A final reason for the dearth of empirical analysis of the political aspects of regulation is a practical one: the lack of easily accessible quantitative data. Data in political institutions are frequently difficult to quantify, hard to conceptualize, operationalize, and measure, and can also be a challenge to collect or otherwise obtain(in contrast to economic indicators).

A major drawback of these accounts lies in the way they conceptualize the relationship among regulators, political institutions, and other external environments. Regulatory bureaucracy has generally been understated as both objects of inquiry and significant explanatory variables in both distributive and majoritarian perspectives. Regulators act very much like legislators. In fact, regulatory agencies would be only neutral reflections of the political process even if we considered them implicitly inbuilt in their theories. Nevertheless, in the real world of politics, it is not surprising that practitioners and policymakers have doubted the veracity of some of the more deterministic aspects of these theories. Few policymakers regard themselves as nothing but black box and believe that regulatory outcomes are the same no matter how regulatory administration works. Given this tendency, neither perspectives fully embraces regulators as explanatory factors in their own right.

To overcome these problems, it is necessary to collect sophisticated data about properties of regulatory bureaucracy and political institutions and to construct an empirical model that captures the dynamics of regulatory redistribution in time and space.

5) This has been driven by a number of forces. One has been regulatory performance, as concerns were raised about the effect of regulation on costs in industries such as airlines, trucking and public utilities(Baron 1995, p.11). Public skepticism against public agencies have also brought attention to the role of public agencies that had in the past been poorly understood, giving rise to calls for elaborate effort to make the public bureaucracy more responsible, adaptable, and efficient(Bok 2002). 


\section{Constructing an Empirical Model of Regulatory Redistribution}

We choose telecom rate policymaking specifically because the industry has gradually deregulated over 20 years, permitting more political intervention by state and federal actors compared to other industries. This setting allows us not only to test the effect of economic, political, and institutional factors on regulatory outcomes across a spatial dimension, but also to investigate the time-varying effect of these factors. In the predivestiture era(before the AT\&T breakup), the regulatory environment in the U.S. was fairly uniform and harmonious with the FCC largely dominant and the state public utility commissions(PUCs) making corresponding changes in their own policies. After divesture, however, purview for the regulation of telecommunications moved from the federal to the state government, and state-level regulation has emerged as the core of telecom policymaking(Teske 1991). States have broad authority under federal rules and jurisdiction, and each one is allowed(required) to decide how much regulation, if any, is necessary. In short, the AT\&T divestiture has led to a great diversity in overall regulatory landscape in the states and thus telecom regulation provides the ideal natural laboratory for empirical analysis, allowing us to test a wide range of economic, political and institutional factors suggested by the literature.

\section{Dependent Variable}

: Residential and Business Cross Subsidy in Local telephone rates(R/B ratio)

We employ the cross-subsidy between residential and business users as the balance of redistribution by intrastate telephone deregulation underway. The setting of rate structure is known as (1) redistribution-driven(Berry 1979), (2) the main function of a state public utility commission(Burns, Costello, Rosenberg, and Darr 1999), (3) reflects theme of ongoing debate on regulatory redistribution, and (4) evokes tensions among state economic and political actors.

Since AT\&T divestiture, state no longer relied as much on long distance revenue to subsidize their local telephone services ${ }^{6}$. So, states have been forced to sustain a high cost local network for themselves, leading frequently to an increase in local rates. Often this increase has taken, in effect, the form of a cross-subsidy from business to residential users. This situation made state PUC regulators responsible for balancing the

6) During the pre-divestiture era, a large sum of subsidy has been transferred from long distance revenue to local telephone operations. This is to help sustain the policy of universal service and make local telephony rates affordable to all consumers. 
level of cross-subsidy between have and have-not users. The question they confronted is how much financial support from business users to residential or high cost users is appropriate and socially acceptable? Less well-off users are possibly excluded from local telephone network if local residential rates become too high on the one hand, while increasing local business rates might force profitable business to shop around for other alternatives for communications on the other hand(e.g. private networks, cable services, etc). By leading to higher residential rates, this might be potential threat as subsidy sources are lost(Cohen 1994). The dependent variable Residential and Business Cross Subsidy in Local telephone rates $(R / B \text { ratio })^{7)}$ is constructed as the ratio of Intrastate monthly Residential Telephone Rates in year $t$ by Intrastate monthly Midsize and Large Business Telephone Rates in year $t$. We believe that it reflects the focus of our analysis well since the issue of regulatory redistributions has usually occurred in densely populated and industrialized areas such as cities. A small ratio indicates that residents are benefiting relative to business groups while a high ratio suggest the opposite, ceteris paribus.

\section{Independent Variables}

\section{(1) Public Utility Commissions (PUCs)}

Four variables are utilized as proxies for state Public Utilities Commissions, regulatory bureaucracy: the method of selecting elites bureaucrats(elected or appointed), the statutory qualification for being elites bureaucrats, the statutory independence of bureaucracy from either the legislature or the executive, and revolving door as a moral

7) Telephone users respond telephone rate changes more than any other category, making it among the most visible and political charged(Cohen 1994). However, telephone rates across states are difficult to compare directly since the states do not follow a uniform rate structure. A simple example is shown below here.

〈Comparison of Sampled Cities in Intrastate Residential and Business Telephone Rates〉

\begin{tabular}{|c|c|c|c|}
\hline \multirow{7}{*}{1990} & $\begin{array}{c}\text { Rock Island, } \\
\text { Illinois }\end{array}$ & Residential & $\$ 19.85$ \\
\cline { 2 - 4 } & $\begin{array}{c}\text { West Palm Beach, } \\
\text { Florida Residential }\end{array}$ & Business & $\$ 60.77$ \\
\cline { 2 - 4 } & $\begin{array}{c}\text { New Orleans, } \\
\text { Louisiana }\end{array}$ & Residential & $\$ 16.69$ \\
\cline { 2 - 4 } & Business & $\$ 44.55$ \\
\cline { 2 - 4 } & Atlanta, Georgia & Residential & $\$ 23.70$ \\
\cline { 2 - 4 } & & Business & $\$ 72.25$ \\
\cline { 2 - 4 } & & Residential & $\$ 23.44$ \\
\hline
\end{tabular}

If we just take either residential or business rates alone as our dependent variable, the result could be underestimated (or overestimated) with a significant level. 
hazard index.

The dummy variable, Elected(or appointed) PUC commissioner is included for hypothesis testing on the likely behavioral difference between regimes of direct election and political appointment. Popular election of regulators is more likely to lead more consumer-oriented regulatory policies since elected regulators are sensitive to voters interests(Teske 1989, 1991; Besley and Coate 2000). The variable ELECT PUC commissioner is a dummy variable, taking the value of one if the commissioners in the state are elected and zero if they are appointed. We hypothesize that those elected by popular votes are more likely to responsive to voters interest than those politically appointed, leading to the median policy outcome favoring residential users over business. Do statutory requirement for PUC commissioners influence the difference of their regulatory behaviors? It is included as a binary variable that takes the value one if specific professional background is required to be eligible to serve on the commission under state legislation and zero if it is not required. Though compelling this might seem, we do not offer any a priori direction prediction about this variable.

Two other important features included here are the statutory independence of a state PUC agency from either the legislature or the executive and the revolving door hypothesis reflecting moral hazard problem. PUC as legislative arm is a dichotomous variable equaling one if a particular state PUC is an arm of state legislature and zero otherwise. If a particular state PUC is an arm of state legislature, a state PUC is expected to respond negatively to a relative increase of residential benefits at the expense of business and large users, ceteris paribus. This is especially true if we consider the theory of congressional dominance(McCubbins et al. 1987). The variable, revolving doors hypothesis, concerns the imposition of restrictions on how long after service on a commission must a commissioner wait before taking a job with the regulated industry. We hypothesize that if PUC commissioners are restricted from working for the regulated industry for a certain period after departure from PUC, they are less likely to be captured by special interest groups while at work. This is consistent with Gormley(1979) and Cohen(1986).

\section{(2) Political and Economic Control of the Bureaucracy}

State Legislature. On any first acquaintance with the idea of congressional control over bureaucracy, one is drawn to the proposition that Congress has instituted a variety of constraints designed to control the exercise of bureaucratic discretion in administrative decision-making. A lot of contributions to the literature seem to begin with the observation that this is self-evident. However compelling this might seem, further 
thought reveals this claim to be inconsistent with the naïve view of congressional dominance argument which is Congress is the only source of influence over bureaucracy. We simply break down competing theories of congressional influence on bureaucracy into three; the case one is that Congress does control the major day-to-day activities of an agency. If it is true, there are no other significant sources of influence; Congress has ability and inclination to control, but it does intervene when it learns that an agency runs away from its will. This view is backed up by famous police patrol/ fire alarm comparison of congressional oversight(McCubbins and Schwartz 1984); the case three is consistent with Moe(1989), saying that legislative influence of bureaucracy is internalized under the politics of bureaucratic structure. That is, it just creates and maintains the structural conditions within which an agency operates.

In attempting to test these competing arguments of congressional influence, our empirical model includes two popular and elementary proxies, the ratio of Democrats to Republican in the lower house and the ratio of Democrats to Republicans in the upper house. Predicting directions of estimates is rough business here. We theoretically expect both estimates to be statistically significant if either the first or the second case is true. Further we rely on directional expectations of these two variables in order to distinguish the former from the latter though weak. By riding with popular belief that Republicans lean toward big business over the poor, we expect both estimates found negative if the fist case is true. If the result is found positive or mixed, no inference is made. Both estimates should be statistically insignificant regardless of the direction if the third is true.

State Governor. Few would disagree the assertion a lack of data create several difficulties for testing political hypotheses empirically. Empirical measures for the executive branch in a state are hardly an exception. Considering this, can we develop a satisfactory theoretical argument of the role the executive in a state does play in regulatory redistribution? Do any partisan-based expectations yield robust expectations here as other studies show? Findings in the American presidency are helpful in our coherent inference. Required is a simple presumption: the situation a governor faces in state politics is the one a president faces in national politics drawn to reduced scale. Studies of American presidents found that presidents are likely to be held responsible for taking action on virtually the full range of problems facing society regardless of party because they have the incentive to think in grander terms about what is best for society as a whole(Moe 1989, 1992, 1997). They have their own agendas that may depart substantially from what even their more prominent supporters might want. This leads them to promote moderation that will eventually increase the social welfare. We utilize 
two serviceable measures for governors here: one is Governors "partisanship and the other is percent of vote cast for Governor elected. So, we expect a negligible effect of Governors' partisanship in regulatory redistribution. The accompanying variable, percent of vote cast for Governor elected is included as a proxy for relative strength of governors' power in a state. The larger the vote share of the Governor, theoretically the more authority he can exercise in a state. Our prediction for this variable is, however, ambiguous as well, and we include it more for completeness vis-à-vis the literature.

Mass Public. There is a body of evidence that differences in public opinion are strongly corrected with state policy differences(Page and Shapiro 1983; Stimson 1991; Hanson 1996). Berry et al(1998) develop an index of ideological sentiments for U.S. states. This variable ranges continuously from zero to one hundred, with scores closer to one hundred signaling liberal sentiment and scores closer to zero signaling conservative one. The variable state ideology score is related negatively to our dependent variable, the rate ratio between residential and business telephone users.

Economic interest groups. It is well established that the setting up and maintenance of a local telecom network(within a state) is more expensive than setting up and maintenance of an interstate network. Because of this, the Federal government mandated that the long distance carriers would have to pay the local carriers an access fee to maintain the local network. This access fee therefore works as a subsidy to high cost local telephony. Of course, this is a service to the consumers of high cost, lowdensity telephone network areas. Local dominant carriers want to keep residential rates down because for two reasons: to justify the existence of the access fee as huge extra revenue sources from long distance carriers and further defend the universal service claim, and because low residential rates serve as implicit entry barriers against potential competitors in the local market.

We attempt to measure these considerations two ways. The first variable, $R B O C$ Intrastate Market Share is taken as a proxy for the pressure from local dominant carriers(especially RBOCs, Regional Bell Operating Companies) on the regulatory agency. We use the RBOC percentage of market share in prescribed telephone lines by state. We expect that the surge and decline of RBOC market share in intra-LATA telephony has a strong impact on state regulatory decision-making. The variable AT\&T market share, a proxy for dominant long distance carriers' influence on state regulators, is a measure of the percentage of AT\&T market share of prescribed telephone lines by state. Since accelerated competition in local telephony is directly linked to the reduction of their burden of cross subsidy from interstate to intrastate telephony, it is reasonable that long-distance carriers like AT\&T will be in favor of local 
competition, not local equality. Since the AT\&T breakup, AT\&T has still remained a market leader, holding about $63 \%$ of the nation's lines in 1998 but minimal(if not negligible) in local telephony market. So, we expect there to be a negligible effect of long-distance carriers' interests on intrastate telephone price distribution.

\section{(3) Control Variables}

The last set of independent variables is general economic controls. Our first two indicators are yearly differences in telephone penetration rates in a state and unemployment rate in previous fiscal year. We use the(lagged one year) state unemployment rate as proxy for the overall state economy. It is widely believed that the state of economy is an important predictor of policy. Scholars of economic development argue that innovation toward a new regulatory regime occurs if these are substantial economic disruptions(Rose 1987; Kahn 1988). An increase in unemployment rate in a state substantially lowers the probability of increasing residential rates(but see Vogel 1989).

The variable Penetration Rate is defined as yearly difference in telephone penetration rate within a state, given by the number of mainlines per capita. We use this as a proxy of the stock of telecommunications infrastructure in a state. We assume that policymakers perceive the possible tradeoff between economic efficiency and equality. If state policymakers interpret the penetration rate as a determinant of the need for further expansion of service(towards universal service), then for a given the number of residential users and telecom infrastructure within a state, the higher the penetration rate, the more weight toward economic equality in policy(thus decreasing the ratio of consumer/business rate).

\section{Results}

Since our sample varies in time(1990-1998) and space(95 cities in 40 states), our econometric model must account for both the time-serial and panel aspects of our data. Data of this form-so-called "time series cross section" (TSCS) data-is problematic in at least three ways: autocorrelation over time, cross-correlations within each panel-year and non-constant error variance(heteroscedasticity). To handle those potential problems carefully, we follow Beck and Katz(1995; 1996; see also Greene 2000) and apply the least squares estimator with Panel-Corrected Standard Errors(hereafter PCSE OLS estimation) here. This method is flexible, efficient, and arguably superior to either the 
〈Table 1〉 The Variables

\begin{tabular}{|c|c|c|}
\hline Variable & Description & $\begin{array}{l}\text { Range } \\
\text { (Theoretical) }\end{array}$ \\
\hline $\begin{array}{l}\text { Residental/Business } \\
\text { Ratio } \\
\text { (Dependent Var.) }\end{array}$ & $\begin{array}{l}\text { The ratio of intrastate residential and business monthly } \\
\text { telephone rates (on average) }\end{array}$ & $\begin{array}{l}0.25-1.32 \\
(0-\infty)\end{array}$ \\
\hline AT\&T Market Share & $\begin{array}{l}\text { Percentage of AT\&T long-distance lines out of Total pre- } \\
\text { subscribed lines in a state. }\end{array}$ & $\begin{array}{l}0-92.9 \\
(0-100) \\
\end{array}$ \\
\hline $\begin{array}{l}\text { RBOC Intrastate } \\
\text { Market Share }\end{array}$ & $\begin{array}{l}\text { Percentage of RBOC Lines out of Total pre-subscribed lines } \\
\text { in a state. }\end{array}$ & $0-100$ \\
\hline $\begin{array}{l}\text { Residential/Business } \\
\text { Line Ratio }\end{array}$ & $\begin{array}{l}\text { The ratio of intrastate residential and business lines in a } \\
\text { state }\end{array}$ & $\begin{array}{c}0.02-4.18 \\
(0-100)\end{array}$ \\
\hline Elected PUC & $\begin{array}{l}\text { PUC commissioners are elected by the public (1) or appointed } \\
\text { by political actors (governor and/or legislators: 0) }\end{array}$ & $0-1$ \\
\hline $\begin{array}{l}\text { Revolving Door } \\
\text { hypothesis }\end{array}$ & $\begin{array}{l}\text { Time Restrictions on Commissioners Departing Commissions } \\
\text { to work for Regulated Industry. If yes }=1 \text {, otherwise } 0\end{array}$ & $0-1$ \\
\hline $\begin{array}{l}\text { Statutory } \\
\text { Requirement }\end{array}$ & $\begin{array}{l}\text { In order to be eligible to serve on the commission, are there } \\
\text { any statutory requirements for professional backgrounds? If } \\
\text { yes, } 1\end{array}$ & $0-1$ \\
\hline Legislative Arm & If the state PUC is an arm of legislature (1) or not (0) & $0-1$ \\
\hline Penetration Rate & Yearly differences in telephone penetration rates & $0.89-1.05$ \\
\hline $\begin{array}{l}\text { Unemployment rate } \\
(\mathrm{t}-1)\end{array}$ & Unemployment rate at previous fiscal year. & $\begin{array}{c}2.2-11.4 \\
(0-100) \\
\end{array}$ \\
\hline $\begin{array}{l}\text { Ratio of Democrats } \\
\text { and Republicans in } \\
\text { Lower Chamber }\end{array}$ & $\begin{array}{l}\text { The Ratio of Democrats and Republicans in the Lower House } \\
\text { in a State }\end{array}$ & $\begin{array}{l}0.18-12.4 \\
(0-\infty)\end{array}$ \\
\hline $\begin{array}{l}\text { Ratio of Democrats } \\
\text { and Republicans in } \\
\text { Upper Chamber }\end{array}$ & $\begin{array}{l}\text { The Ratio of Democrats and Republicans in the Upper House } \\
\text { in a State }\end{array}$ & $\begin{array}{l}0.16-33.0 \\
(0-\infty)\end{array}$ \\
\hline Governor \% vote & Percent of votes cast for Governor elected & $\begin{array}{c}18.9-82.4 \\
(0-100)\end{array}$ \\
\hline $\begin{array}{l}\text { Governors } \\
\text { partisanship }\end{array}$ & $\begin{array}{l}\text { Governors Party Affiliation } \\
\text { Democra } t=-1 \text {, Independent }=0 \text {, Republican }=1\end{array}$ & $-1-1$ \\
\hline Citizen Ideology & Citizen Ideology by Berry et al. (1998) & $0-100$ \\
\hline
\end{tabular}

Parks or Kmenta feasible generalized least squares estimators in finite samples.

The result of PCSE OLS estimation is presented in Table 2, below. In general, the our TSCS result supports our main claims that structural factors of state PUC influence regulators behaviors on regulatory redistribution. Since the interpretation of the coefficients with below four decimal points is complex and confusing, our interest resides in directions of the coefficients and in the level of statistical significance with a substance. 
〈Table 2〉 TSCS Regression Result with Panel Corrected Standard Errors

\begin{tabular}{l|c|c|c}
\hline & $\beta$ & s. $\varepsilon$ & z value \\
\hline AT\&T Market Share & -0.0002537 & 0.0003802 & -0.67 \\
\hline RBOC Intrastate Market Share & $-0.0006592^{* * *}$ & 0.0001819 & -3.62 \\
\hline $\begin{array}{l}\text { The Ratio of Residential/Business Prescribed } \\
\text { IntraLATA Lines }\end{array}$ & -0.0227 & 0.144043 & -1.58 \\
\hline Elected Public Utility Commissioners & $-0.0342565^{* *}$ & 0.0163421 & -2.10 \\
\hline Revolving Door Hypothesis & $0.052173^{* * *}$ & 0.0075181 & 6.94 \\
\hline Statutory Requirements & $-0.0103948^{*}$ & 0.0057893 & -1.80 \\
\hline For PUC Commissioners & $0.528246^{* * *}$ & 0.0107862 & 4.90 \\
\hline State PUC as a Legislative Arm & $-0.0152261^{* * *}$ & 0.002319 & -6.57 \\
\hline Yearly Differences & $-0.0116147^{* *}$ & 0.0036592 & -3.17 \\
\hline In Telephone Penetration Rates & 0.0012981 & 0.0027883 & 0.47 \\
\hline Unemployment Rates (t-1) & 0.0003797 & 0.0025181 & 0.15 \\
\hline Dem/Rep. Lower House & -0.0012305 & 0.0009584 & -1.28 \\
\hline Dem/Rep. Upper House & 0.0006737 & 0.0038633 & 0.17 \\
\hline Governor Percent Vote & $-0.0009456^{* *}$ & 0.0004233 & -2.23 \\
\hline Governor's partisanship & $2.517996^{* * *}$ & 0.257699 & 9.77 \\
\hline Citizen Ideology & $\mathrm{R}^{2}: 0.2485$ & Probability $>\chi^{2}:>.001$ \\
\hline Constant & $*$ & & \\
\hline Number of Cases: 364 & significant at .1 & &
\end{tabular}

The elected PUCS and statutory requirements for PUC commissioners variables are statistically significant with expected signs. These results indicate that state regulatory decisions are strongly correlated with how regulatory bureaucracy is constructed. State PUC as a legislative arm is statistically significant with expected signs, partially confirming the argument of congressional dominance. That is, if a particular state regulatory agency is under state legislature, that agency is more likely being captured by organized industry groups.

Consistent with our expectations, RBOC Intrastate Market Share variable is statistically significant with the expected sign whereas the AT\&T market share is not significant. Citizen ideology is also found to be significant and in the expected direction: more liberal states are found to have a lower relative residential telephone rates.

Of the political and economic control of bureaucracy variables, none of four variablesthe ratio of Democrats to Republicans in the upper and lower houses, and the measures of Governor's party affiliation and percentage of votes received - is found to be statistically significant. This is not unexpected in the case of the Governor covariates, but more difficult to explain for the legislature. We believe that politics matters for 
regulatory policymaking and outcomes, but perhaps equally important questions are when does politics matter and how long until the effects of changes in politics are felt. If politics shape bureaucratic structure, and the design of a bureaucracy reflects the interests, strategies, and compromises of those who exercise political power, then changes in bureaucratic behavior as a result of politics might only be noticed when there are major shifts in the ruling coalition - and even then the changes may take a long time to be measurable. Our data is measured over a relatively short period(1990-1998), and the partisan balance in legislatures perhaps shifts more slowly.

The coefficient on the revolving door hypothesis variable is statistically significant, but in the opposite direction from that expected. In other words, we find that mandatory waiting periods preventing commissioners from immediately working for regulated industries after leaving the PUC are correlated with more residential consumer-friendly rate structures. There are at least two feasible reasons for this unexpected outcome. First, our measure only considers the "exit" phase of the revolving door. As Gormley (1979) points out, the revolving door hypothesis can also involve prior service or employment within the regulated industry. This may effectively limit the pool of potential applicants for the post of commissioner and thus bias the effect of this variable. Finally, Telephone Penetration Rate and Unemployment Rate(t-1) are also significant and in the expected direction.

\section{Concluding Remarks}

We find that the properties of regulatory bureaucracy strongly influence bureaucratic choices on regulatory redistribution matters. Given its chief elected, state PUC serve the interest of residential consumers over business groups during the time period studied. Our findings support neither the distributive vision of government control of industry nor the majoritarian one unconditionally. Rather it shows that how regulatory bureaucracy behaves over redistribution matter quite is conditional, depending on the way regulatory bureaucracy is structured in the web of politics.

What conclusions can be drawn from this analysis? We believe that state regulatory policy outcomes are products of the influences of a multitude of political, economic, and institutional factors. Regulation is neither a simple form of redistribution or protection of the public nor is it the product of capture by regulated industries. Regulation is instead the result of a delicate balance of different and competing interests-economic and political. While much empirical work finds support for various factors as 
determinants of economic regulatory policy and output, most of the literature has only examined subsets of factors, such as economic, political or institutional variables, in isolation. By incorporating these scattered elements into one framework, we feel that this paper is a useful contribution.

This paper also provides a longitudinal approach to state regulatory policymaking in telecom industry in 1990s. Specifically, this paper contributes to the empirical literature on regulatory redistribution by creating and analyzing a new dataset that does just this, focusing on the deregulation of telecommunications industry across American states in the time period between 1990 and 1998. 


\section{REFERENCES}

Banks, Jeffrey S. and Barry R. Weingast. 1992. The Political Control of Bureaucracies Under Asymmetric Information. American Journal of Political Science, 36(2): $509-24$.

Baron, David P. 1995. The Economics and Politics of Regulation: Perspectives, Agenda, and Approaches. In Modern Political Economy, edited by Jeffery S. Banks and Eric A. Hanushek, 10-62. Cambridge, MA: Cambridge University Press.

Beck, Nathaniel, and Jonathan N. Katz. 1995. What to do (and not to do) with TimeSeries Cross-Section Data. The American Political Science Review 89(3): 634-64.

Beck, Nathaniel, and Jonathan N. Katz. 1996. Nuisance vs. substance: Specifying and Estimating Time-Series Cross-Section models. Political Analysis 6: 1-36.

Becker, Gary S. 1983. A Theory of Competition Among Pressure Groups for Political Influence. The Quarterly Journal of Economics 98(3): 371-400.

Bernstein, Marver H. 1955. Regulating Business by Independent Commission. Princeton, NJ: Princeton University Press.

Berry, William D. 1979. Utility Regulation in the states: The policy effects of professionalism and salience to the consumer. American Journal of Political Science 23(2): 26377.

Berry, William D., Evan J. Ringquist, Richard C. Fording, and Russell L. Hanson. 1998. Measuring Citizens and Government Ideology in the American States, 1960-93 American Journal of Political Science 42(1): 327-48.

Besley, Timothy, and Stephen Coate. 2000. Elected versus Appointed Regulators: Theory and Evidence. National Bureau of Economic Research working paper, 7579.

Bok, Derek. 2002. Trouble with the Government. Cambridge, MA: Harvard university press.

Calvert, Randall L., Mark Moran, and Barry R. Weingast. 1987. Congressional Influence over Policymaking: The Case of the FTC. In Congress: Structure and Policy, edited by Matthew McCubbins and Terry Sullivan, 493-522. Cambridge, MA: Cambridge University Press.

Cheilik, Phil. 1999. Reference Book of Rates, Price Indices and Expenditures for Telephone Service. Washington, DC: Federal Communication Commissions.

Cherry, Barbara A. 2001. Crisis of Public Utility Deregulation And the Unrecognized Welfare State. Paper presented at the Telecommunication Policy and Research 
Conference, September 23-25. Alexandria, Virginia.

Cohen, Jeffrey E. 1992. The Politics of Telecommunication Regulation. New York, NY: M.E. Sharpe.

Derthick, Martha, and Paul J. Quirk. 1985. The Politics of Deregulation. Washington, DC: Brooking Institute Press.

Downs, Anthony. 1957. An Economic Theory of Democracy. New York, NY: Harper.

Eisner, James, and Katie Rangos. 1997. The Distribution of Equal Access Lines and Prescribed Lines. Washington, DC: Federal Communication Commissions.

Federal Communication Commission (FCC). 1989-98. Statistics of Communications Common Carriers. Washington, DC: U. S. Government Printing Office.

Fiorina, Morris. 1982. Legislative Choice of Regulatory Forms: Legal Process or Administrative Process? Public Choice 39: 46-52.

Friedman, Milton. 1993. Why Government is the Problem. Palo Alto, CA: Hoover Institute Press.

Fuchs, Edward Paul. 1984. Presidents, Management, and Regulation. Upper Saddle River, NJ: Prentice Hall.

Gormley, William T., Jr. 1979. A Test of Revolving Door Hypothesis at the FCC. American Journal of Political Science, 23(4): 665-683. . 1981. Public advocacy in public utility proceedings. Journal of Applied Behavioral Science 17: 446-62.

Greene, William H. 2000. Econometric Analysis, 4d ed. Upper Saddle River, NJ: Prentice Hall.

Hanson, Russell L. 1996. Intergovernmental Relations. In Politics in the American States, edited by Virginia Gray and Herbert Jacob, 415-51. Washington. DC: CQ Press.

Ka, Sangjoon and Paul Teske. 2002. "Ideology and Professionalism: Electricity Regulation and Deregulation over Time in the American States. American Politics Research 30: 323-343.

Johnson, Ronald N. and Gary D. Libecap. 1994. The Federal Civil Service System and the Problem of Bureaucracy: The Economics and Politics of Institutional Change. Chicago, IL: Chicago University Press.

McCubbins, Matthew, and Thomas Schwartz. 1984. Congressional Oversight Overlooked: Police Patrols versus Fire Alarms. American Journal of Political Science, 28(1): 16579 .

McCubbins, Matthew, Roger G. Noll and Barry R. Weingast. 1987. Administrative Procedures as Instruments of Political Control. Journal of Law, Economics and Organization, 3 
(2): $243-77$.

Moe, Terry. 1992. The Politics of Bureaucratic Structure. In Can the Government Govern, edited by John Chubb and Paul Peterson, 267-323. Washington DC: Brookings Institutions.

Niskanen, William A. 1971. Bureaucracy and Representative Government, Chicago, IL: Aldine.

Noll, Roger G. and Bruce M. Owen. 1983. Political Economy of Deregulation: Interest Groups in the Regulatory Process. Washington, DC: AEI Press.

Noll, Roger G., ed. 1985. Regulatory Policy and the Social Science. Berkeley, CA: University of California Press.

North, Douglass C. 1990. Institutions, Institutional Change and Economic Performance. Cambridge, MA: Cambridge University Press. 1991. Institutions. The Journal of Economic Perspectives 5(1): 97-112.

Page, Benjamin I., and Robert Y. Shapiro. 1983. Effects of Public Opinions on Policy The American Political Science Review 77(1): 175-190.

Peltzman, Sam. 1976. Toward a More General Theory of Regulation. Journal of Law and Economics 19: 211-40. 1989. The Economic Theory of Regulation after a Decade of Deregulation. Brookings Papers: Microeconomics 1989: 1-41.

Quirk, Paul J. 1988. In Defense of the Politics of Ideas. The Journal of Politics 50(1): 31-41.

Reagan, Michael D. 1987. The Politics of Policy. Boston, MA: Little, Brown and Company.

Rose, Richard, 1987. Steering the Ship of State: One Tiller but Two Pairs of Hands. British Journal of Political Science, 17(1): 409-33.

Shepsle, Kenneth A. 1992. Congress is a "They," Not an "It": Legislative Intent as an Oxymoron. International Review of Law and Economics 12(2): 239-56.

Spriggs, James F. 1996. The Supreme Court and Federal Administrative Agencies: A Resource-Based Theory and Analysis of Judicial Impact. American Journal of Political Science 40(4): 1122-51.

Spence, David B. 1997. Administrative Law and Agency Policy Making: Rethinking the Positive Theory of Political Control. Yale Journal on Regulation 14: 407-50.

Stigler, George J. 1971. The Theory of Economic Regulation. Bell Journal of Economics and Management Science 2: 3-21.

Stimson, James A. 1999. Public Opinion in America: Moods, Cycles, and Swings. Boulder CO: Westview Press. 
Teske, Paul. 1991. Interests and Institutions in State Regulation. American Journal of Political Science 35(1): 139-54. . 1995. American Regulatory Federalism and Telecommunications Infrastructure. Hillsdale, NJ: Lawrence Erlbaum Associates Publishers.

Teske, Paul, Sam Best, and Michael Mintrom. 1995. Deregulating Freight Transportation: Delivering the Goods. Washington, DC: American Enterprise Institutes for Public Policy Research Press.

Wilson, James Q. 1980. The Politics of Regulation. New York, NY: Basic Books. . 1989. Bureaucracy: What Government Agencies Do and Why They Do It. New York, NY: Basic Books.

Winston, Clifford. 1993. Economic Deregulation: Days of Reckoning for Microeconomists. Journal of Economic Literature 31(3): 1263-89.

Wood, Dan B., and Richard Waterman. 1990. The Dynamics of Political Control over the Bureaucracy. American Political Science Review 85(3): 801-828.

Wood, B. Dan, and Richard Waterman. 1993. The Dynamics of Political Bureaucratic Adaptation. American Journal of Political Science 37(2): 497-528.

Vogel, David. 1989. Fluctuating Fortunes: The Political Power of Business in America. New York, NY: Basic Books. 